\title{
Nobody Can Deny an Idea Whose Time has Come: Regulations Will Come and Go
}

\section{Bhaskar Vyas*}

Department of Microbiology, Stem Cell Research Division, Total Potential Cells (P) Ltd. and Samanvaya Trust, Vadodara, Gujarat, India

*Corresponding Author: Bhaskar Vyas, Department of Microbiology, Stem Cell Research Division, Total Potential Cells (P) Ltd. and Samanvaya Trust, Vadodara, Gujarat, India.

Clear out the entire forest: but cut not a single tree. So said J Krishnamurthy. We would like to say, let quackery and quacks be entirely eliminated, but let not a single patient be denied who may benefit from stem cell therapy.

Political pundits concur across the globe that the government that governs the least is the best form of government. Karl Marx dreamt of a utopian state of dictatorial governance where state shall wither away!

Howsoever transparent a process and regardless of numerous checks and counter-checks, a sanction to perform is issued at a window with a single sentry- signatory. A higher up at the helm of the affairs, when out of office revealed the secret to us with a wily smile, let everyone vote for the favor of a resolution; let the entire executive body rectify. I know that it can be executed only with my signature. When to sign is not enshrined in any constitution!

Former Vice President of USA, Spiro Theodore Agnew, was bribed by a businessman for a mere $\$ 10000$ ! The businessman, while walking out of Vice President's office was 'shaking in his boots' and ran to the media to clear his conscience. TIME magazine quoted the businessman "I asked myself what I am doing? I am bribing the second most powerful man in the world". Agnew had to resign. A Japanese Prime Minister, Kakuei Tanaka, when caught in a similar act defended himself that it is customary in Japanese tradition to accept a return for a favour.

Charismatic Indian Prime Minister, Indira Gandhi, defended corruption as a global phenomenon. When her son became Prime Minister, he said that only 15 paisa per rupee percolates down to the beneficiary granted by the government.
Received: September 14, 2020

Published: November 18, 2020

(C) All rights are reserved by Bhaskar Vyas.
We have had a rare privilege to sit across R. Venkatraman at Chennai, after his retirement from Presidential Office. We were on our annual retreat at Theosophical Society in Adyar, Chennai. The appointment was readily granted. We reached his residence prepared to wait for the appointment. We were pleasantly surprised to see the waiting area empty.

The office of the previous President of India was about 12 by 12 square feet. There was an office table of about 6 feet by 3 feet. There was 1 executive chair and 3 poorly carved out wooden chairs across the table. Yes, there were some decorations; a flower vase on the table with a few freshly plucked flowers.

He was radiating benevolence from his face. He inquired amicably about the hospital for the inauguration of which he had come to Vadodara. His face gleamed a bit more when we mentioned about Gopal Gandhi, his personal secretary at that time. He asked, whether we had known the latest news about Gopal Gandhi, as he had recently taken over as Governor of West Bengal. After some time, the secretary entered the room and we realized that our time is over. So we stood up and requested for an autograph on the book, 'My Presidential Years'.

He was obviously more pleased and said, "Of course I will sign it. Have you read the book?".

We had read the review in 'The Hindu'. He carried on talking disregarding the fact that our allocated time was up.

"The chapter concerning the mercy petition following the death sentence awarded to the assassin Kehar Singh".

"Why?" 
"The chapter portrays poignantly, a conflict in the conscience of the then President of India. The President is known to be a generously kind hearted person. He would have been inclined to grant the mercy petition. While the chapter describes that the president has to be guided by the legalities that are involved, we understand that you may also have had a few sleepless nights".

"No, I always sleep well, since I conscientiously do my duty and do not worry about the consequences".

During the conversation, he asked us to sit down. Finding him even more relaxed with the personal notes, I ventured to ask him, "Sir, during your long tenure in the office, you may have come across different kinds of people. Did you have any experience; may I use the word 'encounter', with somebody offering grease money?"

"I entered politics at a time when Gandhian ideals were still paramount. My image as a puritan was well known across India. My wife, Janki, (when she travelled to Dwarka in an unreserved compartment) was publicised as religious wife of a sanctimonious husband. But, the Japanese did not know this. They even put pressure that not to accept a return gift is considered a violation of Japanese tradition. I replied to them to add one more piece of the item that they are selling to Indian government as a gift".

"But sir, now generations have passed. Times have changed".

R. Venkatraman closed the discussion by saying, "I see corruption for kickback or whatever name you may call it, as a matter for the personal attitude of an individual. Our heritage is fundamentally based on sanatan dharma. Dharma is a way of life. Of course, people will live their life as per their own choice".

Before leaving the premises, I went over to the personal secretary and thanked him. I said "You have facilitated a memorable instance in our lives. Now may I ask some more facilitation?"

I continued "We have made confirmed railway reservations before leaving Vadodara. Now we are told that Chennai office had not received any such message. The coaches are fully booked; therefore they are not able to help us. Will you please help with VIP quota?"

"Of course. You have been our guests. But even otherwise I utilize this facility for several others".

At the railway station, we approached the coach conductor. He looked at the tickets and said, "Oh, VIP quota. How is Venkatraman sir?"
"He is fine and the gentleman president is still serving the nation".

"Yes, only the other day, I saw him on T.V addressing a gathering at Krishnamurthy Foundation".

As the train started, to our surprise, the supposedly fully booked coach had several berths vacant. Rajni asked, "What is this?" showing the vacant berths.

"The nuances and the metrics of this situation are difficult to decipher. Maybe other seats reserved for VIP quota were not occupied. Waitlisted passengers would have cancelled as we were about to cancel. But rather than mulling over such problematic solutions, let us travel comfortably back to Vadodara".

Rajni asked rather sarcastically and half-jokingly, "Would you not call this corruption?".

"You ask the railway minister for an answer. What we have done is entirely legal and no grease money is paid".

We laughed.

When we decided to leave USA in 1969 it was said to be the year of the gold rush in USA. We had consciously decided to be conscientious that only need and never any greed will be a driving force in our lives.

So as a small private enterprise, engaged in fundamental research, we had thought that we will not have anything to do with governmental agencies. Our initial contact with government officials went really smooth as discussed earlier. Mr. Shashikumar from Dept. of Biotechnology had assured us that New Delhi is really new in the $21^{\text {st }}$ century.

An imperative arose when we decided to apply funding from Government of India agencies. A beneficiary to receive the grant has to have recognition from Dept. of Science and Industrial Research. Both the scientists working with us at that time were repugnant to write an application. I would have conceded to their dislike. But I gathered up myself to prepare a hasty draft and sent it online. But there happened to be a candid talk on the telephone. The voice said, "I am Mr. Deshpande from DSIR. We would like to invite you for a personal presentation". 
"Mr. Deshpande, thank you, but I am under heavy workload".

"We will facilitate you to schedule a date for presentation".

I paused. What does he mean? I went informal and said, "You will be a lifesaver. I am to visit New Delhi for an ICMR sponsored symposium. Can you give me a slot during any of the two days?"

"For sure, Dr. Vyas, please come at 12 noon on the very first day".

ICMR had sponsored a two day workshop with the title, "Stem Cell Therapy: Hope or Hype". In her keynote, Prof. Vatsala indicated the trend that the workshop is likely to gravitate towards hyperbolic claims for therapy with stem cells. I wondered, where is she leading to? But we left to rush for DSIR presentation.

Contrary to the expectations at reception at a government office, I was told that Mr. Deshpande would ask for me after a few minutes since a presentation earlier than mine was in progress.

It was a large hall that would have accommodated around 500 people. I waited at a distance. The earlier presenters left from a side door. I had to wait for a few more minutes till a man rushed past, hurriedly shook hands with Mr. Deshpande and shortly thereafter I was called. Mr. Deshpande began with a conciliatory note. "Your research is on stem cells. So I have called the gentleman from ICMR to be present as well".

I requested help to set up my laptop screen to connect to the projector. Gentleman from ICMR willingly complied. It was like an examiner facilitating a candidate.

I presented a brief that we had prepared for Varshney at Gujarat Venture Finance Ltd.

Mr. Deshpande then asked, "What are your publications for stem cell research?".

"Between 2 promoters, we have more than 50 publications in the respective areas of our disciplines".

"How many of them are for stem cell research?".

"We have yet to begin with our research".

"The department expects that researchers should have at least one publication in the area of dedicated research before granting research status".
"We shall soon publish".

ICMR representative asked, "What innovations have you made in the form of devices?"

"We have devised a contraption by which we transport stem cells from Vadodara to Pune".

"That is not an innovation. Such transportations are a routine".

Within a short time, we were informed that our present status does not justify for research recognition by DSIR. However, we were advised to apply with at least one publication.

Though I had not wanted any recognition, having been denied it spurred me on. This took me to a conference in Bhuvaneshwar.

We prepared a research paper on how the metaphoric semantics in altered states of consciousness may change genetic expression. We have thought for long on the subject and published papers in collaboration with Ernest Rossi. So as to save time for publication in a research journal, we sent the research papers to the Society for Translational Research that was to hold their biannual meet at Bhubaneswar.

Dr. Bharat Aggarwal, chairman, conveyed the acceptance promptly. Journey to Bhubaneswar was a much delayed wish fulfillment. Konark Sun Temple utilizes a wheel as a symbol to represent the journey that the Sun God takes day after day. Thus wheel has symbolized time in Hindu Tradition. We have been enamored with this similar metaphor in Buddhist tradition too. At most Buddhist temples, rotating wheels are displayed. What the devotees may understand about rotating a wheel as a symbol of time does not need to be even questioned. The symbolic meaning to a select few will give a semantic translation to the Wheel of Time. The rest are happy to have paid reverence to a time honored symbol. So it turned out to be a Yatra as well.

Prof. Pathak Sen, professor of genomics at M.D Anderson, Texas, who presided at the time of presentation came across after the session and we sat together for some time. I had made a statement that, "In altered state of consciousness such as meditation, relaxation response, hypnosis and other varieties of religious experiences, etc. (which might collectively grouped as State of Turya; consciousness), the words expand to a semantic transformation so that virtual may be seen as Real". 
He said that, "I am a firm believer that meditation and such states do make an impact on genomics. Such research is underway at our centre. This is increasingly recognized by the West". He was highly interested with research in Ayurveda and he had invited Baba Ramdev to demonstrate Hath-Yoga practices to their centre in USA. He showed interest to collaborate to apply for funding. Although the desired collaboration did not materialize, this instance poignantly shows how the quest for stem cell research can translate into genomics.

Thus I thank DSIR for the Yatra to Bhubaneshwar. We reapplied to DSIR having published this article. Deshpande promptly replied that we need not travel to Delhi as he will soon be visiting Vadodara. He will let us know the dates.

Howsoever hospitable we may try to be, our perceptions with guests have generally turned out to be at variance. We had written to Deshpande that he will be our guest at a hotel nearby. He had accepted. He was received at the hotel and we all had a pleasant dinner.

But a catastrophe was waiting the next morning. Mr. Deshpande was to leave by evening flight back to Delhi. After the inspection, we had organized a sightseeing tour for him. When Nirupa went to pick him up, she deposited his bag at the reception. She then left with Mr. Deshpande to bring him to the stem cell facility. When Mr. Deshpande realised that this meant that he would be billed only for a night's stay he became very agitated.

Deshpande paused, looked sternly at Nirupa. "No, No, No. How can you touch my bag without my permission? My department pays me two days charges and I pay the bill. I do not accept this. Please turn the car and put the bag in my room where it was!"

Nirupa did what she was ordered to do. Lucky the same room was still vacant. Hotel staff understood the metrics. They assured they will prepare a separate bill, etc.

When they arrived, Mr. Deshpande was taken for the inspection by Rajni. Taking me aside, Nirupa briefed me what had happened. I wondered if this would be taken badly by Mr. Deshpande. We swiftly moved on with the presentation. He had only a few questions:

"Where is your stem cell manufacturing facility?"

"The manufacturing facility will be set up at about 20 Miles from here at Biotech Park, Savli. Would you like to visit it?"
"No".

"Have you imported any appliances and machinery?"

"No and even if DSIR recognition will facilitate customs duty exemptions, etc, we are committed to the ideal, 'Be Indian, Buy Indian'. We will not want to buy an imported facility, even if it turns out to be cheaper".

We then invited him to join us for lunch at our home.

He accepted and we dared to relax. We felt we were within touching distance of winning.

Mr. Deshpande spent an hour after lunch with a post graduate from the University who wanted guidance from him. The project had a plan to extract fiber like material from sugarcane waste which could then be made into sanitary pads. Deshpande approved and asked him to go ahead with his research product. He was willing to help. We parted on amicable terms.

After a few days, Deshpande called to say that DSIR was granting approval for three instead of two years. We thanked him.

At our next visit, we went personally to DSIR to thank Mr. Deshpande. The man in his chair, Mr. Rao said, "Deshpande sir has retired some time back. Gentleman that he was, we miss him for his kindness and clean dealings. But I am aware about you. If you need any help, please call-you need not take the trouble to travel to New Delhi.

We had not anticipated even in our dreams that we would need to take the help of the DSIR before the three years were up. But within a short time, another storm blew over that began with SBIRI application already granted!

About three years before this event, Govt. of Gujarat had announced an ambitious plan to host a biotech park at Savli, near Vadodara. They had acquired hectares of land. The park was to be developed in three phases. As part one, a magnificent office building was erected. The most enticing part of the scheme was an incubator. That meant that most of the expensive equipments needed were to be housed there and would be available for use as an outsourcing means. A mission director with spacious offices and a couple of executives were supposed to be functional. As discussed in the earlier chapters, we were the first to apply for 1 hectare of land. We were also the first to be allotted and we immediately paid up Rs. 20 lacs 
to become the first allottee to be handed over the plot. We dug up the tube well to draw water and, a small cottage was built to store masonry equipment.

But there was no sign of an incubator being developed. One could only see some donkeys grazing around there. On periodic visits, our scientist(who took her young toddler with her) would report that her son had had a free ride on the donkey and that some of the masonry tools were being pilfered away. When we complained this to the mission director, he referred us to the Collector, Vadodara. The Collector promptly replied that the plot being in our possession, its security was our responsibility. "If you like, you complain to the police". Thus the time elapsed by. Instead of erecting a compound wall, we planted trees along the proposed fence. It was a pleasure to see them growing tall rapidly in this fertile, barren land.

A few months before the completion of 3 years following allotment of land to us, we got a notice from the executive engineer of GIDC. He drew our attention to the fact if we do not develop the stem cell facility before completion of 3 years, the land will be confiscated back by the government. We had not known this stipulation before this notice arrived. We approached the mission director. He agreed that they had not been able to develop the incubator. Hence the directive was modified to say that the government will take back the land, but will pay back the cost of the land plus an added interest of $6 \%$.

We persisted with the mission director that providing incubator facility was a promise which they could not renegade on. We were being pressurized by the land allocation authority(GIDC) for the return of the land. I wrote a letter saying that I would not return the land and in case of litigation, would cite GSBTM to have a collateral responsibility.

Only then an executive from GSBTM came to met us. We would like to believe that he was a Good Samaritan. He advised that; any litigation apart from long proceedings will put us in a grey zone with the government. Some people at GSBTM may lose their jobs. Another company in a situation similar to ours, has succeeded in selling off their company altogether. GSBTM will have no objection to a similar repeat by us. We were amazed at the win-win situation.

Finding a buyer proved very difficult. The price of the land had rocketed. The only proposed development could be that related to stem cell. Moreover, the land itself could not be sold.
We were almost in a rat-trap. It was our good fortune that an entrepreneur in pharmaceutical business needed the land. They ingeniously suggested a solution. The land cannot be sold: but the company that owns the land can certainly sell itself. Our company had developed research products and applied for government grants. These were the only assets of our stem cell company-Total Potential Cell. We divided our company into two segments. One segment was tagged to the Savli land and sold. We retained the other segment and named it 'Total Potential Cells'.

We frequently asked ourselves; "Does this not amount to a break of contract, does it not mean cheating, is this a criminal offence?" We invoked Saibaba too. Did he answer? We do not know. But we considered this as a SOS situation. The legal experts were absolutely sure that a company can sell out itself. The buyer buys the assets with full understanding of the liabilities. That was a win-win situation. The deal went through and now a large factory operates at this site.

Soon after we were granted the first research project on stem cells by Small Business Innovation Research Initiative-SBIRI. A team comprising of two eminent experts and one financial and business advisor visited us for due diligence. Scientific experts were obviously pleased.

Shortly thereafter, the first installment of the grant money was deposited in the bank account of 'Total Potential Cells Pvt. Ltd'.

We informed DSIR about changing the name of our company. They did not seem too interested. "We understand that in business there can be various reasons for a turnabout. That does not concern us. As long as the same people are doing the same research, we are not inclined to investigate further".

We carried on with our research work. However, fate had other plans and We ran into stormy weather once again...

We were allotted a further grant titled 'Biotechnology Ignition Grant.' Managing director of Biotechnology Industry Research Assistance Council-BIRAC visited our laboratory for due diligence. We sat along with Prof. Bharat Chattoo at Genome Research Centre, MS. University for few hours to finalise our presentations. All the dots and dashes were verified. Just as we thought we had finished, the managing director said, "You have mentioned that you have been granted a SBIRI project. That does not reflect on our records". Promptly, we dashed out the grant disbursement papers. She put 
them in her file and we thought the matter had ended. A short time after, we had a letter from business executive from BIRAC, Mr. Das. The letter was tersely worded. It said, "There are serious discrepancies between the two applications for grant. SBIRI grant was accorded to 'Total Potential Cell.' BIG grant is being processed for 'Total Potential Cells'. Both the companies are different". A copy was sent to Prof. Bharat Chattoo since he was a collaborator.

Anybody who would have read the matter for the first time would have thought that we were upto some swindling. When we met Prof. Bharat Chattoo, he was obviously agitated. He could not hide his annoyance and asked, "Bhaskarbhai, what is this? How could you have done this?"

We pacified the professor and reassured him that there was no swindling whatsoever. We explained the circumstances whereby we had to sell off the company at Biotech Park, Savli. The grants were awarded to the research branch that was separately located as per the rules. The grant money was being utilized for the purpose of same research on mesenchymal stem cells by the same research team.

Prof. Bharat Chattoo then called up the managing director, BIRAC. He assured her that there was no mala fide. Should she desire, we would personally go to BIRAC, New Delhi, to explain. She said she was satisfied but wanted the explanation in writing. The business executive, who had written some scornful accusations softened his outlook. The BIG grant was released. Mr. Rao, at DSIR, also renewed the research recognition with the revised name of the company.

Rajni and I, once again met Mr. Rao to thank him. He was eloquently elaborate this time. He said, "Howsoever well meaning a government servant may be, he has to be constantly aware that he is walking on a razor's edge. He narrated a story of a Delhi transport bus conductor who was found guilty. He had pilfered small change by issuing a smaller denomination ticket than the money collected. The conductor had 29 years of service. He lost not only the job, but the pension rights, etc. as well".

He emphasized that, had the government agencies, SBIRI, BIRAC and DBT not conceded to our representation, he would certainly not take the risk.

We understood.
Fortunately, the storm has blown over.

Both the funded projects have yielded results that have a potential for developing new drugs/therapies for diabetes and osteoarthritis. At the baseline, we have succeeded in establishing that stem cells have the property of translation to all three germinal layers. These cells would undergo translation to the tissue type of the cell that may be needing regeneration.

Further, an autobiography should end just before the writer is about to die. But is not dead. In my instance, the autobiography continues with a self volunteered message to the researchers and many more sufferers with no kind of therapy available to them. I had peripheral neuritis as a complication of type 2 diabetes. All the nerves from head to toe were giving me kind of electrical shocks. Vitamin B-1 supplements and most powerful analgesics failed to provide relief. Thereafter, I resorted to stem cell therapy. At that time, even the consent of compassionate approval was not in vogue.

Necessity is the mother of invention. There will be situations where a precious person in an erudite stem cell research oriented family will have no established line of treatment. In that instance, family, friends and the patient himself would like to be treated with stem cells, regardless of the fact that current rules would not be allow this treatment. We are assured that stem cell application will be available in India and most researchers will provide benefit, at least to the extent of $25 \%$ of improvement. That is the general consensus.

Indian Council of Medical Research came into existence before Independence. The institution is comparable to the Papacy at Vatican. The Pope is satisfied with having proclaimed 10 commandments that prohibit practice of some vices that should be the way for religious heads; one would have expected that ICMR will promote and facilitate research with positive strokes. A monolithic structure and several committees that dart to and fro across India is the only sign of research development at ICMR.

About 50 years back, we had published a research paper about the stress response in burns patients. The clinical significance was that patients with very high stress response index had a poor prognosis. We felt we have achieved a pinnacle of success when this was published in the ICMR journal.

Hence we hold ICMR in high regard. We tried to collate with at least 2 extramural research institutions that are being funded by 
ICMR grant. We cannot name the institutions since the researchers frankly admitted that, 'who cares for their research?'. It was submitted to the parent body ICMR, and it may be lying in some forlorn corner in a multi-storeyed building.

India has a population that is burgeoning with leaps and bounds year after year. India has yet to produce a single new drug. Stem cell science has proven that there are regenerative properties in mesenchymal stem cells. The applications can be vast and varied.

When we read 2006 edition of guidelines for research and therapy for stem cells by ICMR, we were pleased. What leniency! What flexibility! How easily doable again and again! M.S University has numerous faculties in biological sciences. There are eminent clinicians as professors at Medical College, Vadodara. We believe professors have high erudition and ethics. We carefully read the eligibility criteria for being a member of the Institutional Committee for Stem Cell Research. We appreciated the wisdom in excluding the promoters and investigators of the research from being members of the committee. Instead, we personally exhorted the committee members to be our conscience keepers.

We put the relevant literature support on the table. We circulated the guiding principles enunciated at Helsinki.

Thus, we felt that our Institutional Committee for Stem Cell Research will be accorded recognition. Thereafter, selecting an area of research where we have established the proof of concept will naturally follow with an approval from National Apex Committee for Stem Cell Research and Therapy (NAC-SCRT).

But we were in a fool's paradise. We had no understanding of the science concerning the functioning of 'commitology'.

We received a brief communication form Dr. Vijay Kumar, secretary, NAC-SCRT, informing us that NAC has not approved the constitution of our institutional committee for stem cell research. No reasons were assigned. However it was mentioned that we should reapply again.

Anant Marathe and I approached Vijay Kumar at ICMR. When we knocked and entered the room, a gentlemen sitting on the front table typing on a typewriter said, "Hello!".

Introducing ourselves, we said, "We have come to meet Dr. Vijay Kumar, secretary".
Congenially, he said, "I am Vijay Kumar! What can I do for you?".

Showing the letter to him, we said, "We have received this letter from you. We need guidance, what should we do next?".

“Dr. Vyas, I am a secretary to some 800 committees at ICMR, would you believe that such a secretary will have time to look after your company? I can tell you, I have no inclination to follow up. Surely, do carry on your research. My colleague, Dr. Geeta Jotwani will guide you.

"Yes, we have known Dr. Geeta. We shall go to her".

The informal conversation could have been a dialogue between college mates. All three of us remained standing in the ante room. Pleasantly surprised and pleased with this kind of demeanour from Dr. Vijay Kumar, we approached Dr. Geeta Jotwani.

Anant Marathe met Dr. Geeta Jotwani for the first time. An elegant professional lady, courteous yet, certainly no nonsense, perfect professional etiquette. She met us in her small office. Just as we were beginning to talk, Dr. Geeta excused herself to answer a phone call on the landline. We could not identify the caller, but Dr. Geeta told off the man across the line, "Do not make such calls again. I repeat, do not call again!" and she put the phone down.

Anant Marathe and I exchanged glances but Geeta Jotwani was a formally courteous lady. I asked, “Dr. Geeta, we just met Dr. Vijay Kumar, since we got a letter from him. This was a surprise. Usually you have been writing to us".

"Dr. Vijay Kumar is the member-secretary of NAC-SCRT. I am a member, but I am here to help".

She held a hardcopy of stem cell guidelines and patiently explained to us. The principal investigators and co-principal investigators of any project cannot be the members of the Institutional Committee for Stem Cell Research. A few times in between, Anant Marathe received numerous messages on his mobile. Finally, Dr. Geeta conveyed brisk annoyance by turning her face in the other direction. Anant Marathe understood and he switched off his phone.

Meanwhile I argued with Dr. Jotwani. "But, we should at least be accorded a recognition for the constitution of ICSCR".

Geeta concluded, "It is up to the committee". 
Once we were out of the room, having walked a few steps away, Anant Marathe ensured that nobody could hear us. He then exclaimed, "What a formidable woman, sorry not a woman, a lady!".

I mused in my mind. No wonder Anant Marathe is saying this! I said, "We were recanting 12 names of powerful masculine Sun God. Do you remember?".

"Yes, of course. But that was before a presentation that we had to make. What about that now?".

"Praying to 12 different forms of Sun God yielded splendid rewards for us. Devi Lalita has 1000 names to her various forms. One formidable form of this feminine Devi is Durga. When pleased, she can demolish even giant demons to protect a devotee. It is better that one does not brush against such a formidable form of Devi Druga!".

Yes, yes, yes. Both of us concurred.

I had known Dr. Alok Srivastava, haematologist at Christian Medical College, Vellore. He was affable at a conference. So I called him up on the phone. This time, when I identified myself as a researcher in Mesenchymal stem cells, his response was contemptuous, and indignant. He said, "Mesenchymal stem cells? Yes, we could have talked on haemopoietic stem cell research. But, so far, I have not dirtied my hands with mesenchymal stem cells!" And he cut the conversation.

I reported the matter to Prof. Bharat Chattoo. We thought he may have known Alok Srivastava. Instead he voiced reciprocal contempt, "When he says 'he has not dirtied his hands with MSC', how does he justify being the chairman?".

Thereafter, year after year after year we reapplied for recognition of ICSCR. There was a stereotype rejection signed by Dr. Vijay Kumar. After every rejection, Dr. Geeta Jotwani patiently helped us to reconstitute with suitable members. At one of such meetings, Rajni and I showed her grant letters from Dept. of Biotechnology. At that time, Dr. Geeta brightened up with a sparkle on her face. We thought, this time we would get our recognition. Moreover, eminent professorial scientists, such as Dr. Ramesh Bhonde, Dr. Ulhas Wagh, Dr. Ramchandran and Dr. Bharat Chattoo were also the members.

Instead, we were astonished to come across news briefing made by Dr. Geeta Jotwani on behalf of ICMR. This was flashed across most English and Hindi media newspapers. There was a photograph of Geeta Jotwani as well. It said on the headline, 'Stem cell therapy punishable with 2 years imprisonment. Medical licence to be forfeited for the stem cell therapist.

However an option was given for genuine researchers. They were advised to report their research to ICMR with successful results.

Needless to say, most clinicians saw such an invitation as a death threat. Who would want to jump into such a deep well? When we discussed with our friends and well wishers, that we will respond, their response was: "Fools jump in where angels fear to tread". But such an adage was no deterrent to what we have done and that too with genuine research which had achieved favourable results.

I called up Dr. Geeta Jotwani. In a laconic mode, I asked her that she may revoke my medical licence but please she may not put me in prison, life would be hard over there. When I further asked how many replies the ICMR had received, she hesitatingly said only one!

We did not understand at that time that we were having a myopic view. ICMR attitude was generated over a panoramic span of last few years. In 2007, ICMR had held a national conference inviting stem cell participants from across the country. The title of the conference was, 'Stem Cell Therapy: A Hope or A Hype?' At this conference, speaker after speaker presented negative results; except Dr. Habibullah from Hyderabad. This was marginalized as an exception, even though he had reported pluripotent stem cell as a substitute for liver transplant. In concluding remarks, Dr. Vatsala, Chairman, certainly showed bias towards hype rather than a hope.

Thereafter, ICMR convened meetings of stem cell stakeholders in 4 major cities across India beginning from Delhi. Dr. Geeta Jotwani was the convener. She steered the discussion to highlight the newly framed guidelines for research. She emphasized therapy is proven only for hemopoetic stem cells. Once again, we had misinterpreted this gesture as facilitating the researchers. It was aimed at building a prejudiced stance towards MSCs. By this time, there were several centres across the country providing MSC for neurorestoration and such other conditions. Most of them had tried to walk along the dotted guidelines. They had found the doors locked at NAC-SCRT. Several clinicians thereafter decided to walk along on their own. There was immense literature support across the globe concerning stem cell research including Mesenchymal Stem Cells. 
It appears that not only the conscience of ICMR would have been hurt, but multinational pharmas were also against the development of stem cell therapy. Political leverage was exercised. Politicians in power were making statements against stem cell therapy. Only thereafter, ICMR has warned through national newspapers about punishing the clinical doctors. Had it not been for the then Drug Controller General of India, Dr. Ramteke, stem cell research in India would have been thrown into a blind alley. Ramteke had dared to state that he was under tremendous political pressure in a letter that was put in public domain.

We had a chance meeting with Ramteke at a BIRAC conference in Delhi. When we warmly congratulated him, he was politely humble. He was doing his duty as required by the protocol. But the colleague, sitting next to him went on to explain that Ramteke was about to retire in a few months. Had the party in power been re-elected, Ramteke would not have been forgiven and may have even lost his pension.

Ramteke sat mutely smiling. At the conclusion, he simply said, "Men may come and men may go. Institutions last forever. My small contribution as a director of Drug Control would be that I have stopped the practice of pharmaceutical heads dictating their terms to the Drug Control office altogether". The directorate now is completely digitised. Drug trials are to be submitted online and are immediately notified as 'in process'.

In a democratic system, public policy, we came to understand, is in a continuous emerging process. There has got to be checks and counter-checks. Till the process has become a well connected metric with interconnections, so far so good. Instead, when the interacting agencies confront each other with ego problems, it tends to be dangerous. A baby may also be thrown with the bathwater. A government that governs the least is the best form of government. But that is not a purview for the politicians. Their lifespan lasts between two elections. With a few exceptions, when politicians emerge as statesmen, most of the crowd is busy making hay when the sun shines. Public administration is mostly subservient. Their eyes are glued to promotions and pensions. Only a microscopic minority will dare to be defiant. While it may be argued that the other pillars of good governance such as the judiciary and media will maintain balance, we came to understand that the future of small entrepreneurs like us is at a high risk, when treading an uncharted path. Therefore, it is simple: Why risk with innovations? We have a simple answer. There is an itch that is difficult to control- creative itch.
The innovative minority amongst human beings is estimated to be about $2 \%$. While we consider ourselves to be fortunate amongst this minority group, most of our fellows and friends consider this group to be crazy.

When dialogue and debate generates a conflict, not between small stakeholders like entrepreneurs, but between well defined authorities, it is a sign of good omen. ICMR is an autonomous body. Drug Control Authority is a well stipulated authority of over 100 years. In 2017, DCGI decided to consider Stromal Vascular Factor as a drug. The matter was put in public domain. Only one agency objected, ICMR! Reconciliation was provided by including stem cells as a drug. ICMR, DCGI and several stakeholders with small researchers are in a win-win situation with this inclusion. We are now assured that the revocation of medical licence and imprisonment will fall into a forgotten category.

Our pursuit of approval by NAC-SCRT went on relentlessly year after year. Soumya Swaminathan took over as the Director of ICMR after the post remained vacant for a long time. We heaved a sigh of relief. We had met Prof. Swaminathan, the father of Green Revolution in India, at a conference in Hyderabad. When we took a young farmer from Saurashtra, Gujarat, to introduce to the professor of genomics, we had found a really congenial, nationalist to the core person willing to help young, budding agriculturists. Prof. Swaminathan spent quite some time inquiring about the modified genomics of wheat that not only increases the yield but also increases the protein content up to $15 \%$. He even acknowledged that he has read about this research, as certified by Wheat Research Institute of India. He had asked the farmer, "Are you the same farmer, how did you reach the front page of the Economic times?

We wrote about this story to Dr. Soumya. We requested for a meeting at ICMR, Delhi. When we got a prompt appointment, our hopes for NAC recognition went high.

This was indeed precious. We thought this might be a final breakthrough to the deadlock that we had been encountering for a long time. My tendency is to drop my guard when I see a congenial, friendly person across the table. This may be acceptable when nothing is to be bartered. Here there was a motivation to get something that we desired. So, we included Amit Goswami to be a conscientious observer at the meet.

Finding Dr. Geeta Jotwani in attendance with the Director was an additional bonus. Dr Geeta gave a broad smile of welcome and recognition. 
We exchanged pleasantries whilst tea and snacks were served. We elaborated our connections with ICMR. As a medical college teacher, Rajni was awarded a grant for PAP smear testing. Rajni had reported that it was too expensive to be used as a screening test for mass population.

Dr. Soumya smiled and said, "So you have saved national wastage. In my research on tuberculosis, we have saved several precious lives with early diagnostics by mass screening". She looked at me and asked, "What about you?"

"I have published my research findings on stress parameters in burns, way back in 1965. Recently, we sent a research for publication to ICMR journal. Unfortunately it remained unpublished".

Soumya Swaminathan was surprised, "Why?"

Amit Goswami's face suddenly looked stern when I was about to open my mouth that the article was about stem cell research as a therapy for osteoarthritis, instead I swallowed a gulp. Everyone understood that this is not to be discussed at the first meeting. I reminded myself that we had decided to let the relationship develop first.

Regardless of congeniality and hospitality from Dr. Soumya Swaminathan, our homework failed. Sometime later, she opted to migrate to the USA. Of course our hopes were denied and we were left disappointed. We had thought that Dr. Soumya would be a patriotic daughter. Her father's research had ensured that India became a rice exporting nation. Following this Prof. Swaminathan had numerous offers to work outside India. He had refused to emigrate and spent his working life in India.

We have wondered what would be the reason for Soumya Swaminathan to leave for USA. The answer is difficult to guess since women have various roles to perform along with being a professional. Dr. Soumya had worked hard to climb a highly competitive ladder. To be Director at the autonomous ICMR was a pinnacle of success. Along with the perks of her professional job, there were numerous domestic perks available as well.

The salary as WHO would definitely be better. Would this have been the reason she emigrated? Rajni and I would like to believe that motherly form of Devi Lalita, Soumya, would have prevailed. We trust Soumya Swaminathan as Ya devi sarva bhuteshu, matru rupena sangsthita. ! So Rajni and I pray that professional Soumya has also found personal happiness.

We decided to probe with a different mode. The aim was to preempt any action by the surveillance agencies. We therefore wrote to Central Drugs Standard Control Organisation and Drug Controller General of India and invited them to inspect our laboratory. In the request letter, at the end, I wrote, 'Please be our conscience keeper and surely point out whatever mistake we may have made!'

We thought that we had bypassed ICMR! Much to our astonishment, the four member team that arrived for inspection included Geeta Jotwani as the ICMR representative. At the doorstep, Dr. Geeta took Nirupa aside and whispered in her ear, "I have a conflict of interest with other members of the team!".

In our inimitable style, we instructed our scientists to provide full disclosure. At one point, the chief of the team started to grill our scientists. One of them ran over to me in another room and said, "We need help".

When I saw that the questioning had an ulterior motive, I went to the chief of the team and said, "Sir, your name connotes with Bhagwan Shiva. I am in a full disclosure mode, so I say that I have direct relationship with Lord Shiva, the Kailasapathi. I worship him. Please find further faults and make sure that they are on the record".

No wonder that the team was not pleased. They did find 2 or 3 small technical points for not renewing the contracts for maintenance, etc. Thereafter we have not tried to walk into the lion's den voluntarily. At some discomfiture, at long last, we have come to understand that discretion is better than valour!

\section{Conference at Jawaharlal Nehru University, New Delhi}

\section{Collaboration with King's College of London}

One fine day on a sunny winter morning, Professor Pranav Desai arrived and announced briskly: "I am teaching at Jawaharlal Nehru University, New Delhi. I am researching on stem cell scenario in India. I would like to know about your research. If you have time now, I may sit down or if you wish, I may come later".

We have not known this gentleman before. It was rather sudden and with certain surprise that I looked at him. However, we have always respected professors in sure belief that those who commit themselves to a lifetime of study on a particular subject are the professors at universities. A plethora of universities and Deemed uni- 
versities that have appeared across India has vulgarized the spirit of professorship, but not in our minds. We respect professors of whatever brand and from whatever deemed Deemed university. However, Jawaharlal Nehru University is a special kind of its own. Spread across several acres of land with multiple gates and several faculties, at this university, professors believe that teach students; however students educate the professors and the vice chancellors. And, if you belong to JNU, you must have been a leftist. A student graduated from JNU, working for Times of India, gave us a wide coverage thinking that we may have been a card holding leftist.

So we welcomed Prof. Desai pushing aside a couple of scientists from the office. We asked Prof. Desai, "What would you like to know? We are small researchers in private domain. Stem cell is a very wide field. Yet, we aim at finding a product with mesenchymal stem cells".

Prof. Desai asked simple questions. It was clear that he was not an investigating journalist. He had already collected data from several researchers across India and their institutions, including private companies if that was a platform.

It is difficult to guess what about us would have impressed Pranav Desai. One thing was sure about us is that we never hesitate to disclose, in honest, candid, and clear mode, be it Nayantara from Geneva or a journalist from India or Chicago, or be it Pranav Desai. That had led to the discussion about the regulations and further forward to ethics. At conclusion Prof. Desai asked, "Have you studied guidelines published by ICMR for stem cell research?".

"Yes, from 2006 onwards, every time that ICMR revised it".

"If there are several revised editions, would it not imply that there was confusion with the authors?"

"We are ashamed to confess that independent India has not contributed to a single drug discovery. Those Indians who won Nobel Prizes after independence were researching abroad. We would like ICMR to publish a list researches that they have promoted and a catalogue of research that they have thwarted. Rajni Vyas was funded by ICMR way back in the 60s.Her research ended with a negative result that pap smear is not a cost effective method of prevention of cervical cancer. However, with respect to ICMR guidelines, we inform them year after year about our on-going research interests. They have yet to grant recognition to our ethics committee for stem cell research. We do not worry".
About a year later, Prof. Desai sent us a copy of his publication. There was no high scholastic erudition: simply narration of what was going on in India at the time. But attached along with was an invitation to deliver a key note address to the conference that JNU was sponsoring along with King's College of London, with counterparts as Prof. Alex Faulkner Dr. Rupa Dave came along to the conference. She provided a poignant insight into nuances about regulating stem cell research. She raised a counter point that when the world knowledge pool about stem cell research is so overflowing with beneficial effects of regeneration with stem cell, how unethical would it be to deny its access to patients who need it? I completed the key note address with the proofs that trigerminal translation of mesenchymal stem cells is indeed possible.

Presentation by Prof. Alex Faulkner from King's College of London was a dénouement. He said that in UK and Western Europe there is yet no single stem cell product on the horizon. A couple of companies in France have successfully produced large scale dressings. The biological dressings have homologous keratinocytes- epithelial skin cells. Their use is for a limited time and has to be frequently changed. Large treatment centers for burn patients in USA and a few in UK has found them to be life saving.

We were holding our breath to hear the presentation from ICMR representatives. At the conclusion of the first day, it was announced that ICMR representative has withdrawn participation. No loss it was to be, since her slot was allotted as an additional slot to Dr. Geeta Shroff. We have known Dr. Geeta Shroff as a maverick. She has been treating incurable conditions such as Spinal cord injury, Diabetes, Multiple sclerosis, Parkinson's disease, Cardiac conditions, Cerebral palsy. We had seen a patient referred from Vadodara with spinal Injury that returned with a remarkable surprise recovery.

As Geeta Shroff presented, everyone in the audience sat straight with rapt attention. Most of her data was about treatment of spinal cord injuries. She did not have to elaborate on the nature of the injuries to the vertebral column nor did she mention about the type of injury to the spinal cord. Her presentation ran overtime to be taken up further on the next day.

Dr. Geeta Shroff demonstrated that, following treatment with stem cells, spinal cord injury patients were able to walk; some had crutches but a few had no support. We inquired that in an earlier series reported from All India Institute of Medical Sciences, the results were negative. Dr. Geeta stood firm on her ground. "I have only 
my results to demonstrate and defend". Professors from King's College, namely Prof. Brian Salter and Prof. Alex Faulkner asked her about the type of stem cells and regulatory approvals. Dr. Geeta refused to be drawn in this domain. Nor did she demonstrate the images about other conditions like Parkinson's disease or Cerebral Palsy. But she extended an invitation: Everybody was invited at her clinic at the conclusion of the conference to see the patients under treatment.

We had undertaken a proof of concept study with spinal cord injury patients. The patients would range from a near contusion to hemi-section of the spinal cord or a complete trans-section. They may have undergone operative surgery to evacuate blood collection and repair fractured vertebrae. The repair in spinal cord is well understood; though complex in nature.

Grossly speaking, there are two types of neurons in the spinal cord. The motor neurons transmit the impulses of the motor cortex to the muscles of the body, while the sensory neurons convey the sensation to the brain. Each neuron is of specific size and its location is also well defined. Soon after disruption, neuronal cell nucleus sends information to the disrupted end to begin repair whereby the central portion of the cell, extending downwards from the nucleus, known as axon starts regeneration with prolongation, but the spontaneous regeneration ends here. At the site of the injury, there will be organization of the hematoma and invasion by numerous fibroblasts. The proliferating axon will most likely be trapped in such a chaos that its reunion to its own ruptured distal end is highly unlikely. Moreover, the disrupted end undergoes degeneration that affects only axon, leaving its sheath intact. This is intricately understood and is known as Wallarian degeneration. However, how would a proliferating axon connect to its empty sheath may be a micro-molecular engineering. That it does happen, even in isolated cases is a proved positive. But, what would the stem cells may be even of embryonic type contribute, by what properties may not be deciphered for a long time. In human beings, it may be an indefinite time and to evolve the understanding of reparative process with stem cells will need numerous scientists experimenting with various species of animals for a long, long duration. While the scientific hunger for the quest of knowledge for the sake of knowledge will be insatiable, would a clinician wanting to help his patients be non-satisfied that the patient is benefitted for sure?

The process is intense upto 6 weeks but continues upto about 9 months when it completely ceases. Even in such an instance, we have come across one instance of regeneration that cannot be explained on the basis of existing knowledge. A young patient paralyzed for about 18 months down below the waist approached us with a carload of relatives. We explained them the academics and declined treatment. They refused to leave our premises, pleading that they have accepted that failure is most likely- almost certain.

There were decubitous ulcers- pressure sores on the buttocks as well as on one foot, on the heel where bone was exposed. We cleaned up the septic areas. Umbilical cord derived mesenchymal stem cells were injected on the edges of the ulcers as well as poured with drops on the base of the ulcers. Soon there was healthy granulation tissue. This was grafted with pinch graft. Pinch grafts also would have carried some stem cells that are contained at the basal layer of the dermis.

There was complete acceptance of the grafts. Pressure sores healed. Thereafter the patient was treated with autologous bone marrow derived mesenchymal stem cells and umbilical cord derived stem cells intrathically. Umbilical cord blood derived mononuclear stem cells along with very small embryonic like stem cells from umbilical cord blood were injected intravenously.

The patient regained control over micturition and defecation. His sensations recovered at a rapid pace, so rapid as not to be explainable as per the known standards of sensory recovery. Sensory recovery progresses not more than 1 millimeter per day.

The patient was restituted with occupational therapies so as to man a counter at his home shop.

A relative of the patient from the United States donated a handsome amount to stem cell research.

It seemed that Dr. Geeta had hijacked all the interest from the conference. The afternoon sessions drew scant attendance and presentations from the representatives of Drug Controller General of India and some professors of pharmacology were lackluster.

We asked Dr. Geeta to show the type of stem cells that she had used. Her reply was that her scientists had left and the laboratory was closed. But surely there was wonder and amazement to see some of the patients undergoing physiotherapy who have been paralyzed before treatment. Though we would have liked to see other types of patients undergoing neuro-restoration, this was no less a reward. A professor from Jawaharlal Nehru University concluded: "Dr. Geeta, if I were to question you, we will need another confer- 
ence about the academic processes and implicated ethics etc. but if I were to have a spinal cord injury, I would ask the ambulance to carry me to your clinic for sure and I will leave the treatment in your hands with whatever kind of stem cell that you might be utilizing".

Dr. Geeta did not comment further. Our emails remain unanswered. We came to know that in March 2020, 3 companies manufacturing equipments for stem cell isolation and culture sponsored a semi-academic felicitation for women researchers doing stem cell therapy. Dr. Geeta's presentation was based on same clinical material. Shall we conclude that let there be several violations of regulatory guidelines, even if one patient like ours or a researcher like Dr. Geeta produces beneficial results, let the Pundits ponder, as long as no harm is done!

Even pay to publish, since it is addiction

I gave up the academic teaching job at Medical College, Baroda in 1969. Rajni followed in 1973. Her mode of resignation from the academic job is also a paramount proof of our total identity as one. The reporting time at the clinical wards in Sir Sayaji Hospital, Vadodara was at 8:30 A.M. When both of us were working at the medical college, even when I was the head of the unit, I would push off by 8:20 from home; invariably Rajni will be left alone to wind up the breakfast table. If Rupa would not have gone to kindergarten school, she will have to face a few difficult emotional moments before she can be handed over to the babysitter. This would mean that Rajni will invariably be late. The learned professor and the head of the department were at their best as the gatekeepers. He would note the arrival time for every staff member. Rajni would be told day after day: You are once again late today and the two of them will walk to the wards while he will continue the bickering further.

Rajni had worked with tough taskmasters at work. She had endured working conditions of more than 100 hours a week. This bickering also she can easily shrug off. But when we sit down for lunch, everyday she will recount the same sad story of the professors bickering.

Rajni had brought this matter to the attention of her chief, university professor, Dr. Thakorbhai Patel. Instead of help, he was indignant. "You full-timers behave like Pantojis. Why do you not rise to the level of your proven status? You will be one of the first few PhD holders in India in your subject. Your research on the blood volume studies in third trimester of pregnancy in anemic women with less than 4 grams is unique. No parallel in world literature. Why don't you brush aside the meaningless remarks by the professors?"

Rajni had understood that she should live with the situation. She has immense patience and tolerance. But there can always be a last straw that will break the camel's back.

Once, she had had very heavy emergency week. The hospital drained the patients from several districts all around Vadodara. The obstetric delivery patients very routinely brought to Sir Sayaji General Hospital; at times with rupture of uterus. Such emergency operations, at times over-highly anemic patients were life saving situation. Rajni had hardly slept a few hours for 7 continuous nights. On the following day, when Rajni narrated the same story, I saw her wet eyes.

And I decided this is no more. I knew that Rajni would not agree. Over the last few years, we have published more than 50 research papers. While I had detoured, Rajni had a precious aim to be a professor. That she had achieved, but the location was to be at Jamnagar. Now she had more than the requisite experience and post of the professor at Medical College, Vadodara was advertised.

However, my mind was made up. That afternoon only, I personally handed over a resignation letter, with a fake signature, signed as 'Rajni Vyas' in the office.

Next morning, Rajni had a pleasant surprise. She was late as usual. The high professors looked at her and looked down. She wondered, no more reminders! Professor conducted her to the office. He asked, "Rajni, why is this?" and showed the letter.

Rajni wondered, is he going to give me a warning in writing this time? She took the letter and could not stop from uttering, "Oh no!".

Professor asked, "So you said oh no. Do you want to withdraw it?".

By this time, Rajni had gathered up the situation. She said, "No, my mind is made up. I want to quit. I don't want to give reasons, please oblige me by forwarding it with favorable remarks".

From that morning after, there was peace for Rajni for about 6 months. The higher authorities accepted her resignation; but to be relieved only after 6 months! Strange are the ways of government functioning and so are the ways of destiny deciding the destination 
with time specification! At home, Rajni ventilated her aggrievement. Well, the dice is already thrown. Let the barking dogs bark now, if they so choose. She would now have to quit the pristine pure innocence of academic life and will have to jump into turbulent waters of private practice. No regrets: she will measure up to it. She was sorry only on one count; she has been relentlessly persistent in publishing the research. She said, "We have acquired an addiction for research and publishing. How shall we cope with this situation?"

I replied, "We shall derive satiety for this addiction with periodic publication; maybe till such a time that we exist. Let there be no push and drive to publish for promotion. Let this addiction be Saraswati Puja".

We have tried to live up to this resolve: Rajni with more spectacular success than mine. What would have been her PhD thesis got published in the British Journal. Her seminal contribution on unexplained reproductive failure was refused by America Journal. Later with eloquent plagiarism, it was published by the Australian editor in Australian Journal.

When we sent three articles, in a series, on unexplained reproductive failure, the editor had asked Rajni, "How old are you?".

Thus research and publication, apart from being an addiction, has become a magnificent obsession with us.

Therefore, when we received an invitation to contribute for publication, it was a big delight. It was like offering free heroin to an opium addict. We reproduced a very enticing letter from a Chinese editor, now publishing from USA and UK both, as follows. The name of the journal has been changed.

“Dear Dr. Bhaskar Vyas,

I came across your paper "Reversal of Hair Greying following Autologous Adipose Mesenchymal Stem Cell Transplantations A Coincidental Finding" and felt that your work is distinctive for this research domain. This research may indeed prove to be significant to fellow researchers and scientists working in the same discipline.

Taking note of your research interests which matches with our journal domain, may I know more about your current research work? Like we can also develop a network of eminent researcher of your stream worldwide.
As your research work comes under the scope of our journals, I cordially invite you to send your future research articles/papers for publication to Global Journal of Science Frontier Research, DOI: 10.17406/GJSFR.

Regards,

Editor,

Department of Natural Science".

The letter ended with a brief introduction to the Journal. We were excited. But, Anant Marathe had a contrary opinion. He said, "This kind of so-called international or global journals are journals in search of researchers. An open-access journal on the internet costs so much lesser to publish than a hard-copy. We will be lured with various promises. Once we are in the trap, see what happens".

But I argued, "They are promising to publish without payment".

Rajni and I worked overtime for a week and chiseled out an article. Anant Marathe was happy. He said, "Do send it over".

We received prompt acknowledgement. But surprises were to follow. The surprise was in form of a demand asking for payment after acceptance of the article. Yes, we had misunderstood. There was no charge for formatting and typesetting. But, the rest of the charges do apply!

“Dear Dr. Vyas,

We thank you very much for sending your original research article/research paper/review paper and entrusting us to launch it worldwide. In connection with this, please note that every submitted paper will be examined by two peer reviewers to grade it for publication.

In this regard, please note that every submitted paper is doubleblind reviewed by peer reviewers and board members. Acceptance, update suggestion, or rejection depends on their comments. The author is requested to pay only after receiving an acceptance letter for the paper. If any improvement is suggested, the author is asked to upgrade and resubmit the paper. The entire process is expected to be completed within a month. We will try to send you a live tracking link three or four working days. You can use that link to track and update your paper without logging in.

We shall be glad to assist you in case you need any clarification. 
With warm regards,

Manuscript Executive

Manuscript Department".

“Dear Dr. Vyas,

The Article Processing Charges are USD 938 for "Global Journal of Science Frontier Research". This includes all the charges like fees for two Peer Reviewers (USD 469 × 2 reviewers = USD 938), the cost of Hard Copy of Journal (USD 50), Postal Charges, etc.

Since you belong to Research Promoting Zone, Special Article Processing Charges considered for you are USD 106, instead of USD 938. So you can pay in INR/ PKR/BDT etc. (Discounted charges for Zambia, Central African Republic, Afghanistan, Maldives, India, Pakistan, Nepal, Bangladesh, Sri Lanka and Bhutan).

The author is requested to pay only after receiving an Acceptance Letter of the paper".

In 1992, we published our first book towards holistic health. This was with self-finance. While I was in UK, I approached some commercial publishers. One responder had said that even Bernard Shaw, in his early career was published by them. Howsoever high it may have been, we have been averse to vanity publication. Therefore, regardless of the merit, we would not like to pay this internationally acclaimed journal to publish our article. We felt cheated, but they clarified, formatting and typesetting were offered free. That did not include publication and fees for their reviewers! How clever!! It was as good as free entry, only exit charge.

We were not expecting any payments to be made. So we replied,

“Dear Dr. Lenzi, Dr. Wu

Thank you for acknowledging the receipt for our submitted article. We would like to clarify as follows:

We have understood that we are invited. Thereby we are not agreeable to pay any amount whatsoever.

With regards,

Bhaskar Vyas,

Chairman,

Total Potential Cells, Pvt. Ltd.,

Vadodara, India”.
They replied,

“Dear Dr.,

This is to bring in your kind information:

In the light of our "Human Resource Development Division" view, it is very hard for us to provide any discount on your paper.

Being an "Open Access Journal" we provide completely free access to the journals. Hence, the circulation and readers of our Journal are highest which reflects that it is most widely read and of course, this is the best and most preferred way to communicate research work with the world.

As every process and function requires funds to meet the expenditures. The profit-making organizations ask the readers to pay to read the journals. However, such a method reduces the number of readers significantly and is widely known as close cabin publication, while "Open Access Journals" provide free access to the complete paper, but are compelled to ask their Authors to pay fees to meet the expenditures.

Open Access should be seen as a means of accelerating scientific discovery by providing free and unrestricted access to scientific knowledge via the Internet. An essential role of Open Access is the long-term preservation of peer-reviewed scholarly journal articles and research data. Open Access is not only used for journal articles but is also being implemented to theses, scholarly monographs, and book chapters. Promotion of Open Access is very crucial to encourage innovation, socio-economic development, and the flow of knowledge around the world. As such, Open Access can be defined as an instrument ultimately used for public welfare to stimulate the growth of global science, as well as maintain the quality of scientific achievements at the same time.

Restricted access to research findings and scientific discovery through subscription and pay-per-view journals will only impede communication through the scientific community. Also, limited access can also hamper the education and dissemination of scientific knowledge to the aspiring younger generations who are keen to pursue a career in science. Increased productivity and development of science can only be achieved by diffusing knowledge and providing the facilities for creating permanent repositories such as Open Access.

Please feel free to contact us in case of any queries. 
With Warm Regards,

Jennifer Fishburn

Account Manager

Billing Department"

Our reply was,

"Dear sirs,

Thanks. We understand now. We appreciate your situation.

Our situation is that we are unable to pay any amount.

We recieved some comment from the reviewers. We are willing to accept and will send revised article if and when you think you will publish it without any payment from our side.

With regards,

Bhaskar Vyas,

Corresponding author".

Even bartering is international now and no shame to barter for literary products. The journal business manager scaled down the demand as follows:

“Dear Dr. Vyas,

Sorry Sir, best we can do is 2212 INR without hardcopy.

In this case, should we proceed for withdrawal?"

Rajni and I discussed to differ. I would have liked not to pay as a matter of principle. Rajni's view was that we have ourselves gained further insights. There reviewers have taken immense pains to write elaborately. They have given our research 'A' grade.

The amount to pay was not much and the principal to be compromised was no more so sanctimonious. So we agreed.

"Dear Friends and the team,

Thanks.

We shall remit the amount 2212 INR online to your ICICI bank account.

Regards,

Bhaskar Vyas,

Corresponding author".

Both the reviewers have conducted dissecting division into 7 main categories. They are further divided into several subdivision.
Theme, Extensibility of Research, Application of Research, Structural and Compilation Gradation of Article, Interactivity, Title, Abstract and Keywords, Introduction Section, Material and Methods Section, Article Content, Results Section, Discussion/Conclusion Section and Total and Grade. This further extended to (we wondered, good heavens, how much time would they have had to spend even if they were to enter on a template!) Integrity and Analysis of Theme, Depth of the Research, Logical Conclusions, Relevance of the Article, Flexibility of input data, etc.

We shared the experience with Dr. Umakant Dave. In his inimitable mindfulness mode, he had understood both the sides of the situation. He said, "These kinds of open access journals are useful to the beginners. They help them by publishing when an access to the professional discipline journal would be hard for them. They help to build their curriculum vitas. That you do not need. But, they have provided some satiety by providing a small dose of 'heroin' for your magnificent obsession!"

\section{Eureka! A new drug discovery on the horizon!!}

Nobel Prize is customarily awarded to basic sciences. Even mathematics and economics are excluded though awarded through a different route. Drug discoveries are rarely awarded.

Advances in chemistry are basic to drug discovery, since modern medicine heavily relies on discovering newer molecules to serve as therapeutic agents. Discovery of the structure of benzene ring by Kekule happened with a story. There is an ancient Greek symbol 'ouroboros' that depicts a snake holding its own tail with its mouth. Kekule had a dream where he expanded this symbol to 6 snakes and conceptualized a hectagonal structure with carbon atom as a bond. We now know this as the structure of benzene and it has gone on to provide a basic structure for organic chemistry. New molecules begun to be synthesized so as to effectively treat various kinds of diseases. There from most of the newer chemical molecules including for therapeutic use are derived from.

Let us browse through some significant molecules which are the main ingredients of ground breaking medications.

Aspirin (chemical ingredient- acetylsalicic acid) began to be used from the middle of the nineteenth century. It began to be used widely as a pain killer and anti inflammatory drug. If chloroquine, had been available in the first half of the twentieth century, it is possible that Napoleon may not have lost the war against Russia! 
The pinnacle of achievement of synthesizing a molecule is exemplified by synthetic insulin molecule that is now being used as a drug. The drug is composed of numerous amino acids that are chained together to prepare a protein molecule - insulin. Banting (A Canadian orthopaedic surgeon) is credited with success in isolating the active substance from the pancreas. Crucially it is generally accepted that insulin has not been used in animals before being used in human patients.

One of the first drugs used to combat bacterial infections for sulfocetamide.

Diseases such as gonorrhea and syphilis are near extinction, primarily because of penicillin.

Alexander Fleming, a professor of microbiology at St Marys Hospital, London accidentally discovered penicillin. He was culturing microbes in petri dishes and left for two weeks while he was on vacation. When he returned, he happened to discover that there were no microbes around a mold on one of the petri dishes. It was as if the mold had secreted something to inhibit the growth of the colony. On further investigation, it turned out to be what we know now as a strain of penicillin.

In his own words, "One sometimes finds what one is not looking for. When I woke up just after dawn, I certainly didn't plan to revolutionize all medicine by discovering the world's first antibiotic, or bacteria killer. But I guess that was exactly what I did". This revolutionized the practice of medicine. Antibiotics have played a major role in helping doctors combat microbial infections. Since the discovery of penicillin, successively stronger antibiotics have been engineered and made available. Unfortunately now the real challenge is that they rapidly lose their effectiveness because of development of resistant strains of micro-organisms.

India has a rich heritage of Ayurvedic medicine. It is unfortunate that its contribution and knowledge has not been investigated in the same manner as modern medicine. Sporadic interest has shown how extensive the knowledge of this ancient system is. In 1950 's, a plant that has been used since ancient times to lower the blood pressure was subjected to scrutiny and study. Rauwolfia, described in Charak Sanhita as Sarpagandha was used widely in the ayurvedic system for a variety of uses, most commonly asa tranquiliser. After analysis, a new drug, Recerpine was made from the derivative of Rauwolfia to be used as an antihypertensive agent; but was soon replaced with more effective chemically derived molecules.

Another chemotherapeutic drug; Vincristine is derived from a common garden plant, Vinca Rosea or Periwinkle. This is patented now by China; although the plant is there in almost every home in the kitchen garden in India! It is a common plant that grows easily in India amongst other sub tropical countries. When vincristine was isolated from this plant, lily (the original pharmaceutical company who manufactured it) held a monopoly on its manufacture.

Biodiversity in the vegetable kingdom in India is immense. There is huge potential for repertoire for researchers to follow modern scientific models of drug discovery through this vegetable kingdom.

Most human beings are likely to need some kind of drugs during their life-span. Every year the population on the Earth is increasing. That contributes to the expansion of the market size. Thus, pharma-industry as of today is only second to that of the defense equipments.

It was not always so. There was a pharma-company that was benevolent to human beings. The founders of the company had a vision that it will be innovations and research that will propel the progress of business. Burroughs Wellcome Pharmaceutical Company is no more in existence but the Wellcome Trust is now helping scientists early in their careers develop as independent investigators and to advance in basic biomedical sciences. Fortunately for mankind, both the founders of the company Sir Henry Wellcome and Silas Burroughs did not have children. When Glaxo bought over Burroughs Wellcome, most of the funds went to Burroughs Wellcome Fund, which is one of the largest charity foundations. This was a unique model and it is extremely unlikely to be repeated in the current climate that we live in.

In India as in the rest of the world, pharmaceutical companies have grown exponentially in size as well as financially. They are content to simply fulfill their obligations by being compliant to socially responsible funding. In the present century, all isms have become wasms. It goes without saying that business is for profit and without apologies to the yesteryears, profit has seized to be a dirty word in India as well. Whatever may be the curses inflicted on various kinds of isms, the saving grace for capitalism is benevolence. Political philosophy including discussions and debates on isms and 
wasms is a far cry from the story of stem cells. Yet, it does concern the future of stem cell research to the extent that there is well known resistance to this kind of regenerative medicine research since it may affect the status of current in vogue expensive drugs.

With this prelude, at the onset we had known that we were too small to arrive at any drug discovery. We were satisfied with the motto that though large is powerful, small is beautiful. And we have derived strength from a quote from the Dalai Lama, 'If you think you are too small to make a difference, think of sleeping with only one mosquito around.' However, we did not mean to cause disturbance to anyone, for sure.

When Bangladesh became a freshly carved independent nation, population and poverty were abounding. A maverick activist health minister practically banished the multinational pharmaceutical companies from the country. He ruthlessly narrowed the list of 'must needed' medicines to 100 . He supported marketing of these drugs with their generic names so as to bring down the prices at bare minimum. This ensured that people could afford the medicines that they needed to regain or maintain health. But, this may be considered a utopian dream as of now.

Every citizen of the world has a fundamental right to freedom, equality and liberty. Most of the people would want to prolong their life span as long as possible. Along with the desire to increase life span, the demand to look good and youthful is insatiable. Therefore the need for discovery of new drugs, particularly those that can regenerate and rejuvenate is ever-present.

With this scenario, the government has a duty to protect people from hoax claims and fake practices. When we started our careers, medical practice was considered to be both an art and science. Some doctors would even 'smell' a patient or just hold the wrist and count the pulse and will have a hunch as to what was ailing the patient.

Our textbooks of practice of surgery began with an inscription such as, 'I dress the wounds of my patients; God heals them.' Attraction of white blood corpuscles to the site of infection was attributed by theologists universally as an evidence of Divine Design.

God no more exists in medical textbooks. Current medical practice has emerged to be evidence-based practice of medicine. Plethoras of laboratory investigations are available that most of the times can give a correct evidence based diagnosis. Once established, it leaves little room for practicing artful medicine: the usage of the indicated drug with well established dosage modules works out like a mathematical equation. This is the pinnacle of achievement by modern medicine. The honing of stem cells at the site of need is understood as engineered by the properties of molecules present and by the properties of cytokines- biochemical substances secreted by stem cells.

The process of discovering a new drug begins with a concept based on empirical evidence generated out of basic scientific research. The concept is then subjected to animal experiments. When the animals do not have a diseased condition, such as, say fibrocystic disease of the lung, a research model that can replicate fibrocystic disease of the lung in animals is reproduced. The animal species may range from a little mouse to large animals, may be even a deer (remember, one and only clone model devised was Dolly the sheep?) With successful results verified against controlled placebo (placebo is an innocuous inert substance having no physiological properties) trials are conducted. Thereafter, independent ethics committee approvals are needed. Ethics committees have to be approved by government agencies exercising authority to regulate drug control. In India, Central Drug Standard Control Organization and Drug Controller General of India are authorized for approval. In addition, Indian Council of Medical Research issues periodical guidelines for stem cells research. This step as has been our experience is where there is a major road block. Let us explain; We have approached these agencies several times in the course of our work. We would not like to go into great detail; suffice it to say that the narration will surely attract praise for the patience, tolerance and persistence and evoke great sadness at the sordid face of Mother India We have constantly worked with the slogan that not failure, but low aim is a crime. Some may say, 'How sad!' If it was only to express sadness, even failure, we would surely have tried. We have several times mused on Shelly, 'Our sweetest songs are those that tell of saddest thought' or we have sung along with Rabindranath Tagore, the songs of the defeated.

We trust that is the sadness and the sordidness eventually will disappear. And so, let us pass it on without further discussion. At the bottom line, a certain fact does emerge that there must have been a solid reason as to why independent India, independent with more than 70 years has not been successful in discovering a new drug.

Citation: Bhaskar Vyas. "Nobody Can Deny an Idea Whose Time has Come: Regulations Will Come and Go". Acta Scientific Microbiology 3.12 (2020): 75-100. 
Our surmise to find an answer to such a question is simple. Indian system of medicine was based on profundity of wisdom of Charak. On the contrary, present day medical practice is now under the heavy burden of Helsinki Declaration.

We briefly state some guidelines of the Helsinki Declaration. A global association of medical doctors, World Medical Association has promulgated guidelines for conducting a clinical trial on humans: The importance of the objective must outweigh the risks and burdens to the research subjects. This is elementary and would surely be followed without additional burden by an Indian researcher whose basic archetype is to fear God. The protocol for clinical trials should also include information regarding funding, sponsors, institutional affiliations, potential conflicts of interest, incentives for subjects and information regarding provisions for treating and/or compensating subjects who are harmed as a consequence of participation in the research study. This is also easily achieved by Indian researchers.

What is really formidable for India is multi-staging of the clinical trials. A new drug discovery involves formulating a preamble to the concept. This will be based on global research survey of what has already been established with animal experimentation. Proof of concept may further need to be buttressed with proof of concept studies in one or more species of animals and at least 6 human subjects. Further regulatory clearances from the ethics committee as well as drug control authorities have to be taken.

A statistical validation for the results can only be explained when the number of patients subjected to stage 1 of the clinical trialis more than 20. Another parameter may have to be included for statistical validity. That is randomized double blind controlled clinical trial that may use placebos or a less effective tool already in use as a blind control. Clinical trial stage 2, 3 and 4 extend from 50-500 patients. Further evidence needs to be generated with a multi-centric trial.

The patient must not have to carry any financial burden. Riskburden, in case of any adverse event, must be compensated financially to the patients.

Stem cell research is regulated in India by Indian Council of Medical Research. From 2006 to 2017, they have published several editions of the guideline. The guidelines do not have any legal authority. We have endeavored several times, year after year to reg- ister a clinical trial with the drug control authorities(DCGI) in India and have succeeded only once.

to our pleasant surprise, we found that we could register our proposed clinical trials online. with Drug Controller General of India. We constituted an institutional ethics committee and with their approval, we have uploaded more than a dozen clinical trials on DCGI website. I must confess that patience is not one of my virtues! Hence pending approval we began one of the clinical trials. Imagine our amusement when we got retrospective approval for this trial, 3 years after the original application!

One of our trials included working with stem cells derived from fatty tissue. Several insights on the horizon have appeared from the isolation, culture and expansion of these stem cells.

We are able to process about 1000cc lipoaspirate, within a few hours to have a few ccs of stromal vascular factor. It contains a combination of mesenchymal stem cells, a few hemopoietic stem cells and other cells such as endothelial precursor cells, macrophages, smooth muscle cells, lymphocytes, pericytes, and pre-adipocytes. While we contemplated that this minimally manipulated product may as well be utilized since it contains large number of (approximately 30 - 35\% Mesenchymal Stem cells), facilitation happened from CDSCO: Stromal Vascular Factor was proclaimed as a drug in 2017. When this was put for comments in public domain, ICMR asserted that stem cells and their derivatives fall under definition of 'Drug' as per the Drugs and Cosmetics Act 1945, and are further categorized as 'Investigational New Drug (IND)' or 'Investigational New Entity (INE)' when used for clinical application. A similar statement was also issued in a letter to DCGI from International Society for Stem Cell Research. The letter stated "The ISSCR represents more than 4,000 stem cell researchers around the world, including many in India. We are pleased to see that CDSCO is joining other global regulators in endeavoring to develop strong rules to improve the regulation of new stem cell therapies and help assure patients these products are safe and effective. We urge CDSCO to consider the revisions, which will further protect patients from unproven products and procedures falsely marketed as stem cell therapies". Obviously, their bias was in favour of strong rules. Discovery of a new drug from Indian research does not seem to be likely in the foreseeable future in the face of formidable rules and regulations as estimated by Pfizer, new drug discovery in 2020 would cost around \$130 million. 
A moth in utter wilderness, may dream to be a star! That shall never happen. But, a moth may metamorphosize to be a butterfly. This remained our aspiration.

When we got funded for translating adipose derived MSCs to insulin producing cells, naïve as we were, we put our research on the clinical trial domain webpage. We like the fact that computer applications behave like idiot savants. Whatever might be the understanding of semantics by computer, or let us say, by some administrative mischance, our clinical trial to conduct a proof of concept study got approved! I suffered from peripheral neuritis due to diabetes. I felt as if a million small ants were marching up and down my limbs. All known treatments for neuritis did not bring me any relief.

Rajni, (I say it again and again,) is an epitome of patience, perseverance, persistence and forbearance. In contradiction, my personality is prone to proactive action with emotional inputs. True to my impulsive self, I decided that I would be the first and perhaps only patient for a trial to treat this condition with ADMSC.

I was fearless of any adverse reactions since my symptoms were intolerable. I deemed myself to be the researcher, investigator and the patient. I requested Rajni and the rest of my family members to assist and assess my treatment and its response. I am proud to join the privileged group of very few researchers who have tried their research on themselves.

So severe was my discomfort that I refused to listen to the protests of my family. I proceeded to write up the protocol that we would use for the treatment. Aha! It is more than 5 years since; I have not experienced even a single kind of electrocuting spark like jerks anywhere in my body. This is a success story for the stem cells.

Whilst I have benefitted by this procedure, it did put my immediate and extended family through an emotional rollercoaster. Rajni and Nirupa (our younger daughter) were unwavering in their support but kept their fears to themselves.

Rupa our elder daughter insisted that she remain present.

Dr. Chitralekha Dave arrived from Surat for implementing the administration of stem cells and to provide moral support In the morning, I was at a corporate hospital for lipoaspiration which was done under local anaesthesia. As soon as the procedure was over, I insisted on discharge from the hospital with the pretext that, "Hospitals are dirty with invisible microbes that may include methicillin resistant staphylococci bacteria and others such as Escherichia coli, H. pertussis and others. Home is surely a better place". I threatened to walk out against medical advice at which point my family and the staff at the hospital reluctantly agreed to take me home. The stem cells were administered at home.

On the next day, I was comfortable with minimal side effects from the drugs. The family was watching a show on television at about 9 PM. I told Rupa that "I am having a feeling of slight pain on the left side of the chest".

Rupa is working in Britain where the ethos is to take abundant precaution. Acting sharply, in a few minutes she set several wheels in motion. Before I could protest about going back into hospital, my grandsons helped me down four flights of stairs and Nirupa drove me to the hospital. Dr. Dilip Trivedi, Rajni's brother, (senior eminent surgeon in Mumbai) was able to board the overnight train to Baroda and arrived the next morning. I had to spend the night in intensive care unit. Where was the pain? It had disappeared before I sat in the car!. Several investigations and constant monitoring of vital parameters revealed total normalcy. All the same, I had to spend one more day in the hospital for abundant precaution.

Dilip was furious. For the first time he reprimanded me. I remained silent, being at the receiving end. Dilip shot out several volleys of academic questions. "Do you know that there is also a phenomenon called 'host vs graft' reaction? If this were to happen even now subsequently, how shall we take care of you?" When he came to know that I had planned a second session with cultured and expanded mesenchymal stem cells, he ordered them to be thrown away.

Maybe the second shot would have helped me even more. Autologous stem cells will certainly not cause a 'host vs graft' reaction. But there was no arguing the fact that with my brashness, I had roughed up the kind feeling of family members. To date, they have always tolerated this with forbearance, but this time I was left with no illusions that that I would have to answer God Almighty if I acted with brazen bashfulness again".

This solitary personal verification is enough of evidence for us. I can understand that the reader may not agree with the proposed method or doubt that one case is validation for treatment. If we 
ever have the means to do so, I would aspire to conduct a clinical trial for this indication.

Multiple collateral benefits happen to accrue from really diminutive number of diabetic patients who have been part of our trial workload. A patient having diabetic retinopathy spontaneously reported improvement of the vision in both the eyes. Another showed lowering of blood creatinine levels after stem cell treatment. A juvenile diabetic girl having frequent ketoacidosis attacks had no more ketone bodies in the urine. Yet another juvenile diabetic is now a mother with excellent control of her diabetes 10 years after the first treatment.

What amazes us about the collateral benefits is an incidental finding of grey hair turning black. This happened to me and persists with increased number of black hair even after 5 years. We were casual about reporting this research. Surprisingly, it generated worldwide interest and continues to do so even now in 2020! We received an email from the editor of an international journal, which is mentioned in another chapter. It is published in June 2020 issue. This time, using bioinformatics as a tool, we described in this publication as to how we could bypass so many steps, the scientific methods are omitted but even for a lay reader, the logical elegance will be of interest.

Genesis of this report is due to several requests, initially generated by publication in a regional news magazine, Gujarat Medical Journal. We noted, as an accidental finding in our ongoing research on neuro-degenerative diseases treated with Bone Marrow derived Mesenchymal Stem Cells (BM-MSCs) or with Adipose Derived Mesenchymal Stem Cells (ADMSCs). We decided to academically progress the research by publishing it in a journal devoted to stem cell research. This publication in turn has generated global interest and we are receiving reprint requests and the protocols. Meanwhile we have successfully translated ADMSCs to all three germinal layers. Potential is thus expanded to a new drug discovery.

Advances in bioinformatics have so progressed that using computers as a dry lab, enormous data can be accessed. We therefore report on the progression of our research on MSCs as well as results obtainable with bioinformatics on several cytokines that may have impinged our research.

This accidental finding seems to be pointing towards simultaneous stimulatory effect on a small organ such as a hair follicle.
Hair follicles are derived from ectoderm. The hair pigment, melanin will be secreted by glandular cells. which have an endodermic origin! As of now we are unable to explain how black hair growth is seen.

Thus the research highlights that howsoever ambiguous a finding in research, it should not be given a pass. Nature may appear to be playing dice but it does not.

Had Alexander Fleming given a pass to a chance non-occurrence of microbial growth in a particular Petri dish, penicillin may not have been discovered. Therefore, every occurrence, howsoever trivial, must be explained. Researchers usually publish positive results. We should derive inference as to how 10 of the 14 patients did not show the positive signs.

This accidental finding has charted a pathway to possible new drug discoveries. The process will take long to go through various stages of clinical trials. Yet, it is established, with additional evidence as presented in this research that it is plausible that ADMSCs may be a futuristic drug.

The research also highlights how bioinformatics shortens the processes that would have taken a long time to establish in a wet lab.

Another possibility for the discovery of a new drug from stem cell is based on the property of stem cells to undergo translation to the third germinal layer, which is chondrogenic translation. Cartilage in the knee joint in old people gets eroded due to multiple factors. When advanced, it is not treatable with any drugs and requires replacement of knee joints. Here also, a mischance happened when we were given permission by the Department of Biotechnology to do clinical trial with 25 patients. We selected 25 such patients who had both the knees affected and could carry out the trial on 50 knees. This was accepted by funding agencies as not any misadventure but a little cleverness for better utilization of funds. We have said this before that this research has provided hope for survival for our future efforts. Such hope will sustain small researchers like us.

However, nature has so ordained that now in 2020 , there is an urgent need to find a new drug for Coronavirus affected patients. In urgent needs a phrase has emerged, 'compassionate approval'. When this is in context with beneficial effects of stem cells, what 
better boost can stem cell research have? This we will discuss in the subsequent chapter.

Clear out entire forest: cut not a single tree - Contributed by Dr. Rupa Dave, M.S, FRCS

I am venturing to intrude into this domain that is almost forbidden in Britain. Yet, I am doing so at my parental behest. The scenario in India and West are likely to be different. But ethics are perennial in time and space. Human needs, particularly in distress, will also be the same.

I begin with a short autobiographical note since the book is autobiographical. I studied and trained as a medical doctor in India. I have been living and working in United Kingdom since the last 25 years. My study to ethics leading to a Masters in Art (!) was as a part of my National Health Service training. During this period, I often wondered: In India, we gazed at the sky and at times heard intuitive voices. We meditate on a mantra dedicated to Sun God and get inspired with energy. Western world has been altogether a different paradigm. Oriented to logical and rational thinking. It was said, "East is East and West is West; Twain shall never meet". The present century is the time for shortening the distances through electronic speed. I shall try to balance the demand imposed by Helsinki Declaration and further on balance it with the needs of patients likely to benefit with stem cell therapy.

Present day medical treatment revolves around the principle, evidence based therapy. This benchmark is available only to a small segment of hemopoietic stem cells. In contrast, there is a huge literature support that Mesenchymal stem cells may benefit various categories of ailments.

When Papa told me that he had this amazing idea of writing this book, I was delighted.

Just as I was when I was on a trip home and he requested me to accompany him to a conference in New Delhi. He was an invited speaker at a conference that was discussing challenges in stem cell research in India. I have many happy memories of accompanying him when he went to meet dignitaries. It would be a holiday within a holiday.

We travelled on the overnight sleeper train to New Delhi. I marvelled once again how he could easily chat to people and develop a rapport. Whilst talking, he would also mention the work on stem cells he was doing and deliver an indirect pitch in favour of stem cells.
The conference was held at the prestigious Jawaharlal Nehru University. As we waited for the taxi to take us to the venue, he rehearsed his speech with me. He was going to talk about various reasons why the Indian government should support research into the uses of Stem cells and permit their use in various conditions.

Little did I know I was being drawn down a one way street.

He wanted to know what ethical points would support his speech. As I elaborated the principles of Beauchamp and Childress's biomedical ethics, he nodded in agreement. "These are all very good points". He added further, "Rupa, two decades of living abroad has made you thoroughly Western. It appears that you forgot that as a teenager, you have won a prize by reciting Bhagwad Gita. Do you not think that the ethics defined in our culture may be better applied to each and every conflict of interest situation?"

For a while, I was dumbfounded. After a pause I said, "This has not occurred to me. I will need more time to ponder and study". He said, "Now I would like your help in delivering my speech and make sure you integrate these principles as well".

Start with a quote from Krishnamurthi, 'Cut the forest out but do not chop a single tree!'

He was not going to listen to any protest and hence I found myself delivering a speech on why it was ethically and morally right to allow stem cell research and treatments to develop in India.

The four principles are:

1. Respect for Autonomy (respecting the decision making choices of patients and their families thus enabling them to make reasoned informed choices for their treatment). We argued that even though it needed further evidence with large clinical trials, if patients wanted the treatment now, their wishes should be respected. Patients who are ill and their families who suffer with them did not have time on their side-if a treatment was available and they were willing to take the chance then they should be allowed to take it.

2. Beneficence. This consisted of balancing the risks and costs against the benefits of treating. The health care professional would generally act in the best interests of the patient. The small but significant stem cell research community in India were convinced that they were doing the best for their patients. 
3. Non maleficence. Avoid any harm to the patient. Whilst all treatments may have some harm, the benefit should outweigh the harm significantly. Once again, autologous stem cells were derived from the body's own cells-hence the chances that they would cause harm were significantly less. Mesenchymal stem cells are proven to be immune-naive. They may also be included to be a part of treatment, even when obtained from another person.

4. Justice: stem cell treatments could provide similar benefits, risks and costs to all patients across the world.

These points along with the rest of his speech that he has elaborated in a previous story made a strong case for the provision of stem cell treatments in India.

At the time of writing, the world is in the middle of the COVID-19 pandemic. There is no effective treatment although lots of different modalities are being tried (including the use of mesenchymal stem cells). Speed is of essence. Governments all over the world have granted compassionate ethical approval to the development of a vaccine against COVID_19. Gone is the clamour of randomised controlled clinical trials and extensive peer reviews. It takes 10-15 years from concept to bedside for a new drug or vaccine. The Ebola vaccine was developed within a year with the focussed and coordinated efforts of governments, WHO and the manufacturer. There was a clear vision and strategy to ensure that the deadly disease did not spread around the world. A similar hope exists for a vaccine against COVID-19.

If a pandemic can evoke such a response, it seems only ethical to anticipate that with compassionate approval stem cell treatments would be granted the same privilege. It should be substantially more cost effective than mechanical implants or pharmaceutical input, it offers hope for treatment of numerous chronic conditions. This will open up a new vista of vision.

If wishes were horses, everybody will want to ride

Dream we must

One can encounter stories regarding wishful thinking all over the globe, across all the cultures. It will be an unfortunate child who has not been told the stories regarding flying horses and charming princesses! Some of the bestselling books, even in this computer age are those that talk about weird, unbelievable and yet realistic like stories. The sweetest songs have been sung about the dreams lost, yet;
If wishes were horses, everybody would want to ride,

Yet, dream we must since dreams do realize!

Researchers across the globe, working in prestigious laboratories, have produced voluminous data concerning the regenerative and rejuvenate properties of several kinds of stem cells. How do the stem cells bring about this change is also rigorously pursued and debated. Some believe that the stem cells may indeed translate to the required kind of cell at that particular site by honing (-as the Siberian birds do) to the site where they are required. There is also enough evidence that they produce secretions by themselves - cytokines- that are needed for regeneration at the site or possibly all over the body. This would have been enough to justify their clinical use at the beginning of $20^{\text {th }}$ century.

Let us explain why feel that this may have been the case!

Acetylsalicylic acid is now an across the counter drug sold as Aspirin or Disprin.

We met Nobel Laureate Martin Evans soon after he was knighted at Cardiff University, Wales in 2008. He was radiating benevolence and modesty so typical of a suave gentleman. He was bemused as to why we would want to meet him?

We said, "We are researchers in stem cells in a very small way from India".

"What are your areas of research?".

"We are looking to find clinical applications of mesenchymal stem cells".

His face lit up further. "This is all that will matter at the end. I was the first to culture mice embryonic stem cells and cultivate them in a laboratory in 1981. I produced an animal model to replicate fibrocystic lung disease.

Of course that will facilitate further researchers to replicate fibrocystic lung disease and try various drugs and maybe stem cells to arrive at a proof of concept. By this time several animals would have been sacrificed. Of course Society for Prevention of Cruelty to Animals with their vigilant watch will limit the number of sacrificed animals.

But this is a process that is put in practice so as to safeguard human being before clinical application. 
He further continued "As a medical doctor, you would have used aspirin numerous times. Was such a process, beginning today with proof of concept going on to verification of animal models, which then has to be taken to three stages of clinical trials and takes a few years, practiced by Bayer, the pharmaceutical company? Who pioneered its sales in early $19^{\text {th }}$ century?

We do not know. But we do know that apart from effectively helping patients with headache, it has several other clinical applications.

You would have known that there are side effects to acetylsalicylic acid such as brain hemorrhage, bleeding in GI tract, etc. some patients have lost their lives. Is the drug banned from clinical use now?

No. Acetaminophen/paracetamol and ibuprofen discovered as a replacement to aspirin are known to damage kidneys. They would have undergone the stipulated drug discovery protocol. Despite these side effects, Ibuprofen is used by the medical profession with caution".

He paused for effect.

We took our cue - "Sir Martin-, we do not understand the point that you are driving at. Would you kindly elaborate?".

"Before my research will be put to use for the benefit of mankind, at least 10 years will elapsed. This will be with a view to protect human beings. But if some kind of stem cell were to help fibrocystic disease of the lung, and several patients would have lost their lives in the period, is it not unfair to these currently suffering patients who would have otherwise benefitted?".

“To my mind, drug discovery process is a utopian idea. It's common knowledge that multinationals have their business interests to protect. They would have spent millions in the quest of a new drug discovery. Hence from idea to implementation is a long winded process.

I believe that the regenerative properties of stem cells have been proved enough. A way should be found so that stem cells can be used within clinical settings as soon as possible".

We were inspired and enthused by the logical arguments by Sir Martin.
Freud's book 'The Interpretation of Dreams' published in the last year of the $19^{\text {th }}$ century is still a favored pursuit of psychoanalysis. In the book he postulates that dreams arise from deep unconscious mind and find expression as metaphors. William James took it further beyond the unconscious mind and postulated that there is archetypal memory. It is believed by many people across the globe that dreams may herald and may indeed be harbingers of the events to come. We believe that dreams may also be so programmed that they have a formative power to generate material events. Regardless of hypothesis, it is indeed true that idea is the first reality.

Therefore, we visualize that

- Someday there will be a new dawn so as to benefit the largest number of patients with affordable priced stem cell products.

- A mutual consent by the patient/family of the patient and the drug dispenser/medical doctor will be all that might be necessary to use a stem cell product.

- Helsinki declaration may prevail for the affluent nations. There shall be a new ethical code of conducting clinical trials based on ethics, proclaimed in the Bhagwad Geeta.

Of course, quacks abound and should be prevented. However in a free democratic society, people cannot be stopped from having faith in fakirs, sants and mahatmas. And hidden persuasions can be effectively deployed by hiring proficient people. Advertising as a means of mass communication has graduated to a refined profession.

Stem cell research and therapy in India including our own, came across a stormy threat in 2014. General elections in India were due. Political parties need funding for their election campaigns.. The situation was saved by a courageous, risk-taking and yet duty conscious Drug Controller General of India, Arunkumar B. Ramteke.

Ramteke put a letter in public domain. He wrote that he is under constant pressure from the health secretary and the health minister to put severe restrictions on stem cell research and therapy. As per the requirements, objections to such a notification had to be filed within 45 days.

We immediately objected to any blanket package of restrictions. We do not know how many stem cell researchers would have objected. Crucially the 45 days ended after the results of the general 
elections were announced and a new government was sworn in. We personally met Arunkumar B. Ramteke, congratulated and thanked him. Initially modest and reticent to discuss more, when prodded he disclosed that at that time he had put in more than 30 years of service. He was due to retire within 2 months. He had foreknowledge that authorities, even higher than the health minister were interested in stopping stem cell research. It was rumored that if the move was not implemented, Ramteke may be suspended and an ordinance may be promulgated. Ramteke concluded: "I am a small man, risen from the ranks with perseverance to my duties. A suspension at very nearly the end of a stellar service record would be very hard for me and my family. However I did not support the decision as an individual. Before putting the matter in public domain, I asked myself only one question, 'Am I doing my duty as required by the service rules?' When my conscience answered me yes, I did not think any more about the consequences". We salute the spirit of Ramteke and dream of a day when India will have many more public servants like Ramteke.

Support for stem cell treatments also came from across the continents, Barrack Obama, the then President of USA put forward a fervent appeal. He said researchers doing profound, in-depth research under microscope and experimenting with animals in the laboratory have enormous time; crucially a patient whose life is under threat cannot wait till conclusive evidence is obtained. Barack Obama relaxed several restrictions imposed by his predecessors that prevented the outgoing flux of stem cell researchers. However, the norms for conducting clinical trial are the same as of today-they take so long to complete.

According to the current standards, a new drug has to be tested under numerous protocols including double blind controlled clinical trials before it can be used. Simply stated, while one group of patients is given the drug under testing, the other group of patients with the same conditions is given a placebo. Statistically significant number of patients must improve and the placebo given patients should be significantly less in improvement and in number then the drug can be said to be effective. It is a well known fact that this takes a lot of time and requires a huge financial investment.

The world currently finds itself in the throes of Covid-19 pandemic. There is no cure available. There is no drug that can eliminate the virus. There is no vaccine to protect against the virus. Survivors from the conditions would have managed to do so with their own immune processes. Since, one of the properties of stem cells immune protection and enhancement, an Israeli firm produced a stem cell product derived from the placenta. It was used by the clinicians at Mt. Sinai Hospital in New York. If the normal regulatory approval were required to be obtained, it may have taken several years. However, a new term emerged: compassionate approval. In the anticipation that such an approval would be granted, the stem cells were administered to 12 critically ill Corona patients. 10 of these came off the ventilators and were subsequently discharged.

"What we saw in the very first patient was that within four hours of getting the cells, a lot of her parameters started to get better," said Dr. Karen Osman, who led the team at Mount Sinai.

The doctor said she was encouraged by the results, though she was hesitant to link the stem cell procedure to her patients' recovery.

"We don't know" if the 10 people removed from ventilators would not have gotten well had they not been given the infusion of the stem cells, she said. "And we would never dare to claim that it was related to the cells".

She explained that a "randomized controlled trial" would be the only way "to make a true comparison".

It is obvious that there can be no repeat run for the cured and discharged patients: the patients would be thankful that they are alive; relatives may have spent or donated some amount that cannot be equated with a life saved. But, the treating doctor has acted with wisdom. Being able to wean and discharge 10 out of 12 patients should amount to a stupendous success story; certainly anybody could be proud of. But, Dr. Karen's response was subdued. Discretion is better than valor. Had Dr. Karen claimed to be responsible for this first time success story about usage of stem cells and favorable results, she would have been subjected to a lot of criticism from her peers and other researchers. By admitting that there has not been a randomized controlled clinical trial to test the efficacy of the stem cells, she ensured that the report would survive the anticipated disapproval. She was satisfied to put on record what actually happened and admitted in advance the limitations.

With such an occurrence, we asked: how far long the ethical yardstick-or the ethical regulatory sword may be wielded? If a double controlled clinical trial would have been given to another 12 patients and if most of them would have died, who should be held responsible? 
Therefore, we dream of a day when even an anticipatory compassionate approval may not be needed in a situation where it is plausible that some benefits are likely to ensue from stem cell therapy. Under the pretext of protecting the people, large scale dictatorships have emerged. This has happened inspite of democratic checks and counter checks. A government that governs the least is a utopian idea and would surely be the best government. We continue to dream of a day when India wakes up to our dream that stem cell research and therapy will be governed the least in India.

We rewrite the poem by Rabindranath Tagore as follows:

Where the mind is without fear and the head is held high;

No stem cell researcher will ever fear

Persecution, imprisonment or revocation of license.

Where knowledge and research sharing is done without reserve;

Where the world is united in pursuit of research

Affordable to all in regenerative domain

Where the publications come out from the depth of true research;

Where tireless striving produces reproducible results

Stretching its extension to multiple situations;

Where the clear stream of reason has not lost its way

Into a stereotype aping of the Western models,

In copy and paste prototype

Where the mind is led forward by Nature and God that you may be led

Into ever-widening thought and action

Into that heaven of regenerative medicine, my Father, let my country awake.

\section{Acknowledgement}

We acknowledge help from Vatsal Naik for transcription and pre-publication editing.

\section{Assets from publication with us}

- Prompt Acknowledgement after receiving the article

- Thorough Double blinded peer review

- Rapid Publication

- Issue of Publication Certificate

- High visibility of your Published work

Website: https://www.actascientific.com/

Submit Article: https://www.actascientific.com/submission.php

Email us: editor@actascientific.com

Contact us: +919182824667 